\title{
National Low-Level Waste Management Program Final Summary Report of Key Activities and Accomplishments for Fiscal Year 1996
}

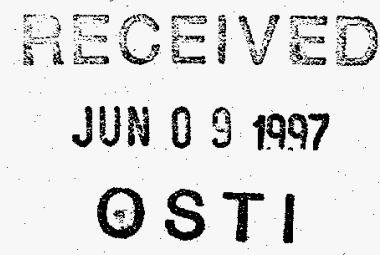

R. S. Garcia

DISTRIBUTION OF THIS DOCUMENT IS UNLIMITED 


\section{DISCLAMMIER}

Portions of this document may be illegible in electronic image products. Images are produced from the best available original document. 


\begin{abstract}
To assist the Department of Energy (DOE) in fulfilling its responsibilities under the LowLevel Radioactive Waste Policy Amendments Act of 1985, the National Low-Level Waste Management Program (NLLWMP) outlines the key activities that the NLLWMP will accomplish in the following fiscal year. Additional activities are added during the fiscal year as necessary to accomplish programmatic goals. This report summarizes the activities and accomplishments of the NLLWMP during Fiscal Year 1996.
\end{abstract}

\title{
DISCLAIMER
}

This report was prepared as an account of work sponsored by an agency of the United States Government. Neither the United States Government nor any agency thereof, nor any of their employees, makes any warranty, express or implied, or assumes any legal liability or responsibility for the accuracy, completeness, or usefulness of any information, apparatus, product, or process disclosed, or represents that its use would not infringe privately owned rights. Reference herein to any specific commercial product, process, or service by trade name, trademark, manufacturer, or otherwise does not necessarily constitute or imply its endorsement, recommendation, or favoring by the United States Government or any agency thereof. The views and opinions of authors expressed herein do not necessarily state or reflect those of the United States Government or any agency thereof. 


\section{CONTENTS}

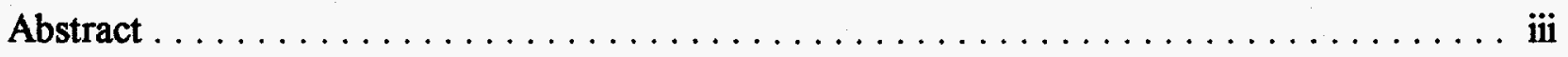

INTRODUCTION AND PURPOSE $\ldots \ldots \ldots \ldots \ldots \ldots \ldots \ldots \ldots \ldots \ldots$

NATIONAL PROGRAM

SUMMARY OF ACCOMPLISHMENTS FOR FISCAL YEAR 1996 . . . . . . . . . . 3

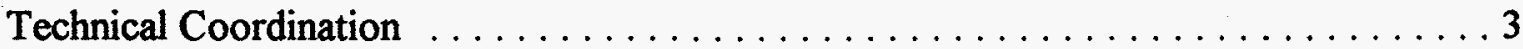

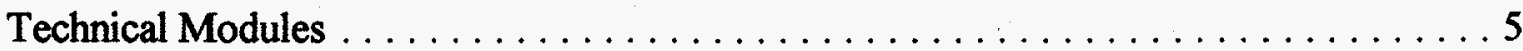

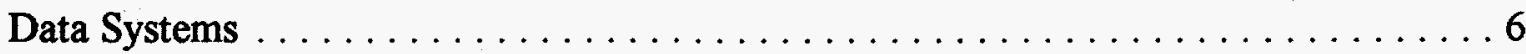

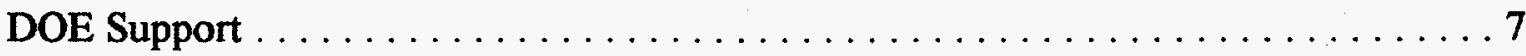

Direct Technical Support $\ldots \ldots \ldots \ldots \ldots \ldots \ldots \ldots \ldots \ldots \ldots \ldots \ldots \ldots$

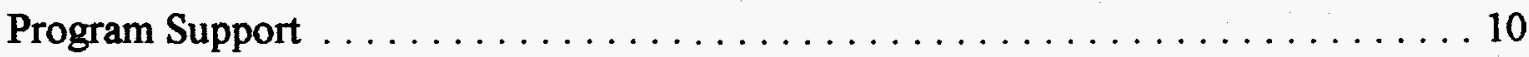

GTCC LLW PROGRAM

SUMMARY OF ACCOMPLISHMENTS FOR FISCAL YEAR $1996 \ldots \ldots \ldots \ldots \ldots 11$

Figures

1. National Low-Level Waste Management Program Workshop Evaluation Ratings . . . . . . . 9 


\section{NATIONAL LOW-LEVEL WASTE MANAGEMENT PROGRAM FINAL SUMMARY REPORT OF KEY ACTIVITIES AND ACCOMPLISHMENTS FOR FISCAL YEAR 1996}

\section{Introduction and Purpose}

The National Low-Level Waste Management Program (NLLWMP) supports the Department of Energy (DOE) by assisting the states and compact regions in their efforts to manage low-level radioactive waste (LLW). The states and compact regions were assigned this responsibility under the Low-Level Radioactive Waste Policy Amendments Act (LLRWPAA) of 1985, Public Law 99-240.

The NLLWMP is the single organization within the DOE and commercial LLW systems that maintains the national perspective on low-level radioactive waste management. The NLLWMP is the repository for both the historical and current perspective on technical, institutional, regulatory, and political activities and issues related to national low-level radioactive waste management. This report summarizes the activities and accomplishments of the NLLWMP during fiscal year 1996 (FY 1996).

As a subset of the NLLWMP, the Greater-Than-Class C Low-Level Waste (GTCC LLW) Management Program supports the DOE in ensuring the safe and efficient management and disposal of GTCC LLW generated by Nuclear Regulatory Commission (NRC) and Agreement State licensees. The responsibility for ensuring the safe disposal of GTCC LLW was assigned to the Federal government by Public Law 99-240.

For FY 1996, activities of the NLLWMP were divided into six major categories: Technical Coordination, Technical Modules, Direct Technical Support, Data Systems, DOE Support, and Program Support.

Major accomplishments by the NLLWMP and the GTCC LLW Program in FY 1996 include the following:

- The National Program organized and presented the 17th Annual DOE Low-Level Radioactive Waste Management Conference on December 12-14, 1995, in Phoenix, Arizona. Conference proceedings were distributed on computer diskette to the participants and also were placed on the Internet, providing international access to the proceedings.

- The 1995 State-by-State Assessment of Low-Level Radioactive Wastes Received at Commercial Disposal Sites was issued. The 1993, 1994, and 1995 State-by-State 
reports have been loaded on the Internet. This provides national and international access to the report.

- The GTCC LLW Program completed NEPA action, contingency plans, and modifications for the Sealed Source Storage Facility.

Detailed summaries for each of these major accomplishments and other activities of the NLLWMP and the GTCC LLW Program can be found in the following sections of this report. 


\title{
National Low-Level Waste Management Program Summary of Accomplishments for Fiscal Year 1996
}

\author{
Technical Coordination
}

The NLLWMP provides a mechanism to exchange pertinent information among states, compact regions, Federal agencies, LLW generators and brokers, and legislators on the development of new LLW disposal capacity and management techniques. Individual tasks in this group (with the associated accomplishments during FY 1996) are as follows:

- $\quad$ Annual DOE Conference on Low-Level Radioactive Waste Management

The 17th Annual U.S. Department of Energy Low-Level Radioactive Waste Management Conference was held December 12-14, 1995, in Phoenix, Arizona. The conference was opened with a keynote speech by Steve Cowan, Assistant Secretary, Office of Waste Management. The keynote address was followed by plenary panel discussion, The Changing Landscape and Future of Low-Level Radioactive Waste Management. The panel was facilitated by David Leroy with the following panel members: John Weingart, Director, New Jersey Siting Board; Jerry Scoville, J. J. Scoville \& Associates; John Bartlett, The Bartlett Company; Jack Barraclough, Representative to the Idaho Legislature; David Rossin, Center for International Security and Arms Control at Stanford University; and Steve Cowan. The closing plenary session featured Dr. Leon Lederman, Nobel Laureate. Teachers from the Phoenix area also attended to hear Dr. Lederman talk on science education.

The conference was co-sponsored by the University of Idaho. This partnership between the DOE-ID, INEL, and the University of Idaho enhances the conference and reduced overall cost to DOE. Evaluation results indicate that state and DOE participants believe this is the most cost-effective forum to meet the range of technical and institutional needs for the national LLW management mission.

The proceedings were distributed on computer diskette providing a cost savings for the NLLWMP. The proceedings were also put on the Internet, providing international access to the proceedings.

\section{Host State Technical Coordinating Committee}

The Host State Technical Coordinating Committee (TCC) provides an opportunity for technical representatives from states developing new LLW management facilities to coordinate and promote the exchange of information among states, address technical issues of mutual interest to states, and focus and suggest 
priorities on research and development activities. The NLLWMP supports the TCC and moderates three meetings held each year. This fiscal year the TCC addressed the following topics and issues:

- factors that make up "reasonable assurance" from the regulatory standpoint

- the practical aspects of low-level radioactive waste disposal facility design and some potential problems when construction begins

- an overview of the Fort Hancock and Sierra Blanca proposed sites for the Texas LLW disposal site

- toured the Fort Hancock and Sierra Blanca sites in west Texas

- toured the Waste Isolation Pilot Plant near Carlsbad, New Mexico.

The NLLWMP sponsored meetings with the National Conference of State Legislatures (NCSL) providing a forum for legislators to discuss current issues. The working group conducted a panel discussion with legislators about economics, community acceptance, and political issues for proposed or existing disposal facilities within their districts.

- Conference of Radiation Control Program Directors

The NLLWMP participated in a meeting with members of the Conference of Radiation Control Program Directors (CRCPD). The Committee E-5 resolved peer review comments on the draft Environmental Monitoring Report for Commercial Low-Level Radioactive Waste Disposal Sites (1960s through early 1990s). The committee also encouraged the Program to pursue the possibility of waste form tests and prepare topical reports in accordance with the U.S. Nuclear Regulatory Commission's Branch Technical Position on Waste Form.

- Volunteer Siting Plan Working Group

The Volunteer Siting Plan Working Group brings together those states and compact regions that are pursuing a voluntary process and facilitates exchange of information about the successes and failures of their efforts. States participating in this working group include Connecticut, New Jersey, Massachusetts, New York, Pennsylvania, and Michigan. 


\section{Technical Modules}

The NLLWMP develops printed information that addresses topics of general interest to states and compact regions in establishing new LLW management systems. The Program develops, compiles, organizes, and documents related research and industry data into information modules. Such modules may be in the form of reports, handbooks, plans, or bulletins. During FY 1996, the NLLWMP issued nine technical documents listed below:

- $\quad$ National Institutes of Health: Mixed Waste Minimization and Treatment, DOE/LLW-218

- MWIR-1995 DOE National Mixed and TRU Waste Database User 's Guide, DOE/LLW-233

- Analysis and Suitability of DOE Facilities for Treatment of Commercial LowLevel Radioactive Mixed Waste, DOE/LLW-235

- $\quad$ Assistance Available Through the National Low-Level Waste Management Program, BP781-0196

- Comparison of Selected DOE and non-DOE Requirements, Standards, and Practices for Low-Level Radioactive Waste Disposal, DOE/LLW-225

- Comparison of Low-Level Waste Disposal Program of DOE and Selected International Countries, DOE/LLW-236

- $\quad$ State-by-State Assessment of Low-Level Radioactive Wastes Received at Commercial Disposal Sites, 1995 DOE/LLW-237

- Performance Assessment for a Hypothetical Low-Level Waste Disposal Facility, INEL-96/0375

- Commercially Available Low-Level Radioactive and Mixed Waste Treatment Technologies, DOE/LLW-240.

Also, cooperative studies continued with the University of Texas including those in the following areas: fissure studies, natural analogs for trench caps, and optimization of vadose zone monitoring.

A mobile low-level radioactive waste verification system was demonstrated at the 17 th DOE Low-Level Radioactive Waste Conference, and operated with actual low-level radioactive waste at the Idaho National Engineering Laboratory. 


\section{Data Systems}

The NLLWMP maintains a comprehensive LLW data base system that states, compact regions, DOE, and other Federal agencies may use to conduct analyses, make decisions, and apply in other special situations. Much of this information can be found on the National Low-Level Waste Management Program's newly-created home page.

\section{- Data Acquisition}

Manifest records for 1995 LLW shipments for disposal have been obtained from commercial LLW disposal site operators and incorporated into the Manifest Information Management System. As of October 1, 1996, the system includes disposal information from 1986 through September 1996. The Manifest Information Management System is now available on the Internet at the following address: http://mims.inel.gov

- $\quad$ Customer Support

The National Program maintained a customer support hot line to the Manifest Information Management System. Information was developed and transmitted to the Integrated Data Base (IDB) program detailing the commercial LLW disposed in 1994. The IDB is published for the U.S. DOE Office of Environmental Restoration and Waste Management. Data were also supplied for the Annual DOE Report to Congress.

- Low-Track

The Low-Track, PC-based software developed by the NLLWMP, is capable of providing inventory management and tracking functions. Low-Track is now capable of generating Barnwell and Uniform Manifests for shipping. New features of this system include waste classification and conversion to international units. This software has been field-tested and is being used by the U.S. Army, states, and LLW generators. The Nuclear Regulatory Commission is working on a certification.

- Report Publication

The 1995 State-by-State Assessment of Low-Level Radioactive Wastes Received at Commercial Disposal Sites (DOE/LLW-237) was prepared and distributed. This report provides information about LLW disposed by states at commercial LLW disposal facilities, and also provides summary data from 1986 through 1995. This report is an important planning tool for states and compact regions for future LLW disposal. The 1993, 1994, and 1995 reports are available on the Internet at the 
following address: http://www.inel.gov/national/nllwmp.html.

- Document Information System

A Document Information System is maintained by the NLLWMP. This data base program includes information about documents from all the states and compact regions and the documents produced since 1979 by the NLLWMP. Over 1,200 documents are accessible through this system. The document catalog is a tool for identifying documents related to low-level radioactive waste management and disposal facility siting, regulation, performance, etc. Documents from the Nuclear Regulatory Commission, Department of Energy, National Low-Level Waste Management Program, and compact regions are included in the system. The system is now licensed to exchange/monitor publications.

\section{DOE Support}

The NLLWMP provides support, on request, to DOE on LLW issues throughout the fiscal year. During FY 1996, the NLLWMP performed the following supporting tasks:

- Distributed over 3,800 documents to a standard distribution list for new NLLWMP documents.

- Responded to 78 ad hoc requests from DOE and others, including the following:

- Developed issue papers for DOE-HQ

- Andrews County, TX proposed site for DOE waste

- Surcharge rebate rulings

- Compact briefing sheets

- California land transfer

- Developed a brochure describing the Program's products and services. The Assistance Available Through the National Low-Level Waste Management Program is a quick reference guide to services available through the NLLWMP. Technical assistance provided is concisely described in the brochure and highlights services available through the NLLWMP. The brochure describes workshops, LLW information products, and state and compact region support provided by the NLLWMP. The brochure can be found on the National Low-Level Waste Management Program's Home Page. 


\section{Direct Technical Support}

Under this activity, the NLLWMP provides support to states and compact regions that is targeted to meet their specific needs and requests.

\section{- Workshops}

The NLLWMP conducted 24 workshops during FY 1996 serving 748 customers. Many of these workshops were developed to meet special state and compact region needs. The workshops and the states they were conducted in are:

- $\quad$ Conflict Resolution (Nebraska)

- $\quad$ LLW, Mixed Waste, and Biomedical Mixed Waste (Florida)

- $\quad$ LLW Minimization (California (2), Massachusetts)

- $\quad$ LLW Transportation (Texas (2), Nebraska)

- $\quad$ How to Survive a Public Hearing (Texas (2))

- Quality Assurance (New Jersey)

- $\quad$ Regulatory Issues (California (3), Arizona)

- $\quad$ Team Building (Pennsylvania)

- $\quad$ Risk Communications (Pennsylvania)

- $\quad$ Speakers Bureau Training (Pennsylvania)

- $\quad$ Performance Assessment (Connecticut)

- Volunteer Siting (Massachusetts)

- $\quad$ Radiation Fundamentals and LLW Management (Washington)

- $\quad$ Karst and Limestone Geology (Ohio)

- $\quad$ Providing Testimony (Texas (2)) 


\section{NLLWM Program Technical Assistance}

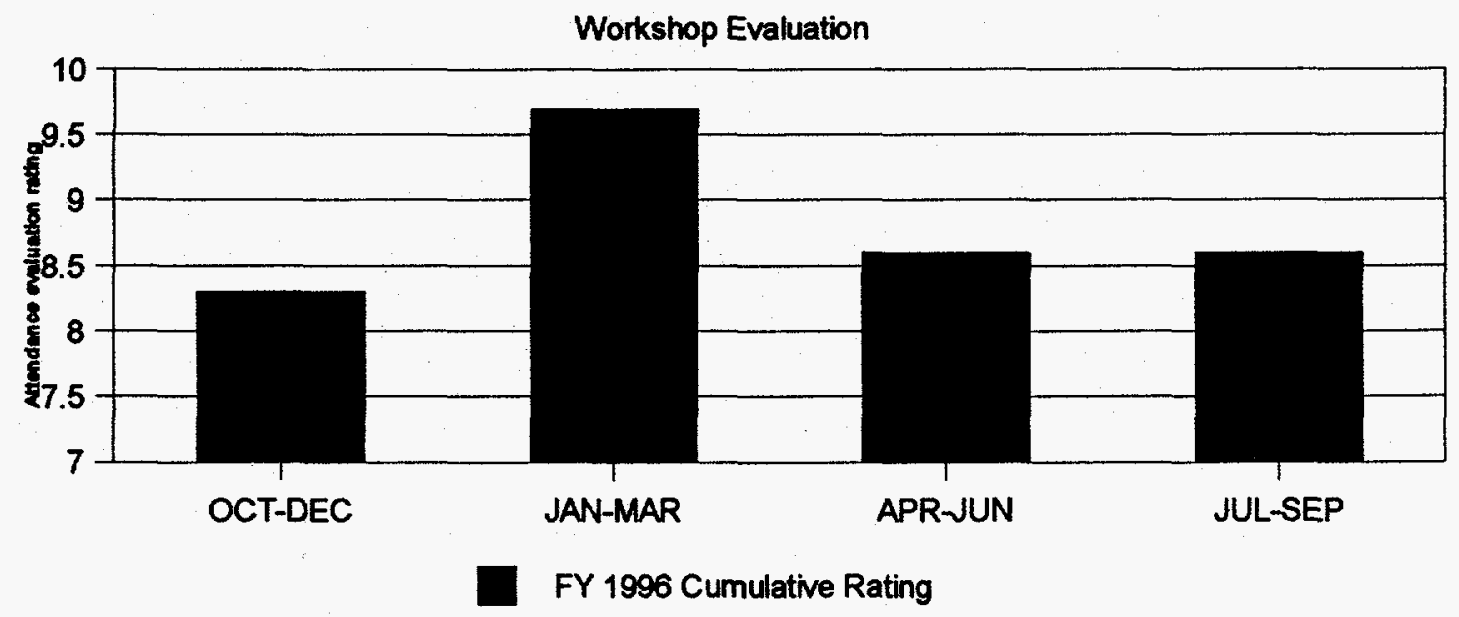

Figure 1. National Low-Level Waste Management Program Workshop Evaluation Ratings

- State-Specific Requests

The NLLWMP supports states and compact regions in their efforts to resolve specific technical and institutional issues. Program resources are directed to specific requests from states or compact regions. The following state-specific requests were initiated in FY 1996:

- Assistance in producing a 3-D model of a low-level radioactive waste disposal facility for Massachusetts (completed in FY 1996)

- $\quad$ The New Jersey Low-Level Radioactive Waste Disposal Siting Board requested two tasks: 1) to develop a resource library for volunteer host communities, and 2) to develop a booklet containing questions and answers to commonly-raised concerns (carry over to FY 1997)

- $\quad$ Provide assistance in developing a guide for local officials on how to discuss whether to be a host for Pennsylvania's low-level radioactive waste disposal facility (completed in FY 1996)

- $\quad$ Provide assistance to evaluate potential doses and to determine the relative importance of engineered barriers at a hypothetical low-level radioactive waste disposal facility in Pennsylvania (completed in FY 1996) 
- $\quad$ Assist in the review of a performance assessment section of a closure plan submitted to the State of Washington by US Ecology (it was determined that US Ecology needed to rewrite their plan. It was resubmitted and it is again being reviewed for completeness.)

- $\quad$ Support the USGS analyses of water from core samples taken from an area adjacent to the closed burial site near Beatty, Nevada. The analyses are designed to check the tritium analyses from soil gas samples by helping determine the sources of tritium and aiding in the interpretation of the data. (mostly completed in FY 1996. Some work will carry over into FY 1997.)

- $\quad$ Program Liaison

The NLLWMP provides technical expertise to assist states and compact regions in conducting and reviewing LLW management activities, and provides information to Congress, states, compact regions, Federal agencies, the public, and other interested parties as requested. Other objectives include maintaining contact with state and compact region representatives in order to identify technical assistance needs and monitor progress of new LLW management system development. Accomplishments in this area include the following:

- Liaisons attended compact and advisory committee meetings and provided information on request

- Liaisons developed and coordinated specialized training for staff personnel

- $\quad$ Liaisons developed special research materials, such as comparisons of host state siting criteria, and distributed Program materials to states and compact region officials. Activities were particularly heavy for the Southwestern compact, the Southeast compact, and Texas.

\section{Program Support}

The program support task provides information, planning, project management, and technical support for the day-to-day operation of the NLLWMP. Key accomplishments under this task include the following:

- Developed brochure describing the Program's products and services. The Assistance Available Through the National Low-Level Waste Management Program is a quick reference guide to services available through the NLLWMP. Technical assistance provided is concisely described in the brochure and highlights Program services available. 


\section{GTCC LLW PROGRAM SUMMARY OF ACCOMPLISHMENTS FOR FISCAL YEAR 1996}

Significant FY 1996 accomplishments in the GTCC LLW Program are listed below.

- $\quad$ NEPA action for Sealed Source Storage Facility completed (October 1995)

- Sealed Source Storage Facility contingency plans completed (January 1996)

- Sealed Source Storage Facility modifications completed (January 1996)

- Formation of the Readiness Assessment Board (January 1996)

- Prepared the final Report to Congress for DOE-EM Review (July 1996)

- $\quad$ Provided GTCC update for DOE Civilian Radioactive Waste Management (RW) (August 1996)

- Preliminary visits to SRL and NTS to explore capabilities for interim storage of utility GTCC (August/September 1996) 